\title{
KEBIJAKAN PEMERINTAH PADA BIDANG PERLINDUNGAN SUMBER DAYA GENETIKA LAUT DI INDONESIA DALAM RANGKA MENJAGA DAN MENGELOLA SUMBER DAYA ALAM LAUT
}

\author{
Abdul Atsar \\ Fakultas Hukum Universitas Singaperbangsa Karawang \\ Jl. H.S. Ronggowaluyo-Telukjambe Timur- Karawang \\ Email : atsar_abdul@yahoo.com
}

\begin{abstract}
Indonesia is a country that has a wealth of marine genetic resources of interest to researchers and scientists to do research in order to produce findings and new innovations. Thus, the necessary arrangements are clear and unequivocal. The implementation of the system of intellectual property rights requires not only good legislation in the field of intellectual property, but also need to be supported by the Administration, the rule of law as well as the optimal dissemination programs about intellectual property rights. At present, Indonesia has had a device regulation in the field of intellectual property that protects marine genetic resources, namely Act No. 13 of the year 2016 about patents. Since the year 2000, the filing of the application for intellectual property rights can be made at the offices of the Ministry of Justice and human rights areas. This can be seen with the promulgation of Act No. 13 of the year 2016. Through this Act an awful lot of refinement and the addition of the former patent laws i.e. Law No. 14 of the year 2001. As for the formulation of the problem in this research is how Government policy in the field of the protection of genetic resources of the sea in Indonesia in order to maintain and manage the natural resources of the sea. The results showed that decisive action from the Government in preventing violations of patents in the form of damages for Patent holders that have been used by other parties without permission from the patent holder. It also ordered the violators with stops in producing goods that have been patented.
\end{abstract}

\section{Keywords : Government Policy, Legal Protection, Sea Genetic Resources}

\begin{abstract}
Abstrak
Indonesia merupakan negara yang memiliki kekayaan sumber daya genetika laut yang menarik bagi peneliti dan ilmuwan untuk dilakukan penelitian guna menghasilkan temuan dan inovasi baru. Sehingga diperlukan pengaturan secara jelas dan tegas. Pelaksanaan sistem hak kekayaan intelektual yang baik bukan saja memerlukan peraturan perundang-undangan di bidang HKI yang tepat, tetapi perlu pula didukung oleh administrasi, penegakan hukum serta program sosialisasi yang optimal tentang hak kekayaan intelektual. Pada saat ini Indonesia telah memiliki perangkat peraturan perundang-undangan di bidang kekayaan intelektual yang melindungi sumber daya genetika laut, yaitu Undang-Undang Nomor 13 Tahun 2016 tentang Paten. Sejak tahun 2000, pengajuan permohonan HKI dapat dilakukan di kantor-kantor wilayah Kementerian Hukum dan HAM. Peningkatan perlindungan terhadap sumber daya genetika laut merupakan wujud keberpihakan pemerintah pada bidang perlindungan sumber daya genetika laut di indonesia dalam rangka menjaga dan mengelola sumber daya alam laut. Hal ini dapat dilihat dengan diundangkannya Undang-Undang Nomor 13 Tahun 2016.
\end{abstract}


Melalui Undang-Undang ini banyak sekali penyempurnaan dan penambahan terhadap Undang-Undang Paten yang dahulu yaitu Undang-Undang No. 14 tahun 2001. Adapun rumusan masalah dalam penelitian ini adalah bagaimana kebijakan pemerintah pada bidang perlindungan sumber daya genetika laut di indonesia dalam rangka menjaga dan mengelola sumber daya alam laut. Hasil penelitian menunjukkan bahwa tindakan tegas dari pemerintah dalam mencegah terjadinya pelanggaran hak Paten berupa ganti kerugian bagi pemegang Paten yang telah digunakan oleh pihak lain tanpa seizin pemegang Paten. Selain itu juga dengan memerintahkan si pelanggar menghentikan kegiatannya dalam memproduksi barang yang telah dipatenkan.

\section{Kata Kunci : Kebijakan Pemerintah, Perlindungan Hukum, Sumber Daya Genetika Laut}

\section{A. PENDAHULUAN}

Sejak dahulu kala Indonesia dikenal sebagai negara kepulauan terbesar di dunia. Dengan luasnya lautan yang dimiliki banyak potensi kekayaan laut yang dapat kita manfaatkan untuk kesejahteraan rakyat Indonesia. Indonesia memiliki potensi sumber daya laut yang sangat besar. Selain ikan, berbagai sumber daya lain terdapat di sini, seperti pertambangan, rumput laut, terumbu karang, dan sebagainya. Semuanya memiliki nilai ekonomi yang sangat besar untuk kesejahterakan rakyat, terutama kaum nelayan. Nelayan memiliki posisi yang cukup strategis mengingat dua pertiga wilayah Nusantara adalah laut. Namun seringkali nelayan tidak berdaya secara ekonomi dan terjerat kemiskinan. Karena itu perlu upaya untuk memberdayakan nelayan demi meningkatkan kesejahterannya. Sumber daya laut yang ada di Indonesia memang sangat besar, jika dikelola dengan baik, maka bisa meningkatkan kesejahteraan rakyat, khususnya nelayan dan masyarakat pesisir. Sehingga ketahanan ekonomi akan terwujud.

Indonesia merupakan negara kepulauan yang mana dua pertiga wilayahnya adalah perairan laut. ${ }^{1}$ Jauh berabad-abad yang lampau, kepulauan yang sekarang berjajar di Negara Kesatuan Republik Indonesia sering disebut dengan beraneka ragam. Berbagai sebutan tersebut membuktikan bahwa cikal bakal negara Indonesia sebagai negara kepulauan sudah dikenal luas masyarakat Internasional. Hal ini dapat ditemukan dalam catatan bangsa Tionghoa, kawasan kepulauan disebut dengan Nan-hai (Kepulauan Laut Selatan). Sedangkan catatan kuno Bangsa India menamai kepulauan ini sebagai Dwipantara (Kepulauan Tanah Seberang), Bangsa Arab menyebut jaza"ir al-Jawi untuk merujuk pada kepulauan Jawa. Bangsa Eropa menyebut Indonesia pertama kali sebagai Kepulauan Hindia. Secara geografis hampir 70 persen wilayah Indonesia merupakan perairan yang sangat berpotensi menyimpan kekayaan laut yang luar biasa, mulai dari potensi sumber daya genetik laut, dan industri kelautan.

\footnotetext{
1 Agustina Soebachman, 2014, Sejarah Nusantara Berdasarkan Urutan Tahun, Surya Media Utama,
} Yogyakarta, hlm. 14 
Di era global seperti sekarang ini, sektor maritim memainkan peranan yang sangat penting dan strategis dalam berbagai macam aktivitas, baik politik, ekonomi, sosial, pertahanan dan keamanan serta aktivitas yang berkaitan dengan hubungan antar pulau dan antar negara, khususnya dalam bidang perdagangan nasional maupun internasional. Pertumbuhan volume perdagangan internasional dalam beberapa tahun terakhir sebagai akibat proses globalisasi telah menuntut perlunya pengembangan sektor kemaritiman agar dapat beroperasi secara efektif dan efisien sehingga dapat bersaing dengan negara-negara lain. ${ }^{2}$

Sebagai dampak dari globalisasi dan perdagangan dunia (bebas) telah membawa perubahan besar bagi sektor maritim Indonesia. Dampak tersebut mengakibatkan pula perkembangan yang pesat di bidang teknologi industri maritim. Keadaan tersebut membawa kecenderungan dalam hal penggunaan sarana transportasi, jenis kemasan dan kapasitas angkut yang semakin besar. Hal ini juga akan berpengaruh terhadap keberadaan Sumber Daya Manusia (SDM) pelaut dengan kualitas dan kuantitas pekerjaan yang semakin besar.

Laut Indonensia memiliki kekayaan sumber daya berlimpah. Namun pengelolaan dan regulasi yang mengatur penggunaan kekayaan laut tersebut dinilai masih kurang memberi keuntungan bagi negara. Sehingga perlu upaya-upaya dari berbagai pihak untuk bekerjasama dalam pemanfaatan kekayaan laut secara optimal dan terarah.

Hukum diharapkan mampu mengatasi berbagai permasalahan yang timbul terkait dengan sumber daya laut terutama sumber daya genetika laut. Hukum harus dapat memberikan perlindungan bagi karya intelektual sehingga dapat mendorong masyarakat untuk mengembangkan daya kreasinya di bidang ilmu pengetahuan, teknologi, seni, dan sastra, yang akhirnya bermuara pada tujuan berhasilnya perlindungan hukum terhadap sumber daya gentika laut.

Paten adalah hak khusus yang diberikan, negara kepada penemu atas hasil penemuannya dibidang teknologi untuk selama waktu tertentu melaksanakan sendiri penemuannya tersebut atau memberikan persetujuannya kepada orang lain untuk melaksanakannya. $^{3}$

Sumber Daya Genetik (SDG) Laut mencakup semua spesies tanaman, hewan maupun mikroorganisme, serta ekosistem laut dimana spesies tersebut menjadi bagian daripadanya. Sementara Pengetahuan Tradisional (PT) yang terkait dengan sumber daya biologi tersebut adalah merupakan komponen intangible dari sumber daya itu sendiri. Kombinasi dari pengetahuan tradisional dan sumber daya genetik berpotensi untuk diambil

${ }^{2}$ Badan Penelitian dan Pengembangan Departemen Perhubungan RI, 2005. "Studi Kebutuhan SDM Transportasi Laut", Laporan Akhir Penelitian, BPP Dephub, Jakarta, hlm.1

${ }^{3}$ Richard Burton Simatupang, 2002, Aspek Hukum Dalam Bisnis, Rineka Cipta, Jakarta, hlm. 76. 
keuntungannya secara komersial yaitu dengan mengembangkannya menjadi produk dan proses yang bermanfaat.

Potensi komersial yang melibatkan sumber daya genetika laut terkait telah berkembang sangat cepat dalam dua dekade terakhir seiring dengan perkembangan yang pesat dari industri bioteknologi. Perkembangan dan kemajuan ilmu bioteknologi telah menjadi perangsan dan simultan bagi berkembangnya potensi ekonomi, pemanfaatan dan komersialisasi Sumber Daya Genetika Laut. ${ }^{4}$

Kondisi ini, bisa menjadi peluang bagi Indonesia beserta beberapa negara berkembang lainnya, yang notabene berada di wilayah beriklim tropis dengan kekayaan sumber daya genetik yang melimpah, seyogyanya bisa menjadi potensi dan karunia yang sangat luar biasa dalam pemanfaatan sumber daya genetik tersebut. ${ }^{5}$ Akan tetapi faktanya berbeda jauh dari apa yang dicita-citakan oleh negara beriklim tropis dengan sumber daya genetik yang sangat melimpah tadi.

Biopiracy menjadi hal yang sering terjadi yang menimpa negara-negara berkembang dengan kekayaan sumber daya genetik yang melimpah. ${ }^{6}$ Negara maju dengan kemampuan teknologinya cenderung telah mengambil keuntungan yang tidak adil dari sumber daya genetika dan pengetahuan tradisional dari negara-negara berkembang. Pemanfaatan ekonomi dari Sumber Daya Genetika Laut dengan menggunakan bioteknologi, khususnya di bidang Farmasi dan Bioteknologi tidak dapat dipungkiri berkembang dengan dukungan sistem Hak Kekayaan Intelektual, khususnya Paten dan Perlindungan Varietas Tanaman (PVT). ${ }^{7}$

Potensi ekonomi melalui pemanfaatan dan komersialisasi Sumber Daya Genetika Laut umumnya memakai pengetahuan tradisional serta menjadi perangsang timbulnya biopiracy, dimana pemanfaatan meliputi eksplorasi maupun eksploitasi dari Sumber Daya Genetika Laut dan pengetahuan tradisional terkait, kini terindikasi dilakukan melalui beberapa cara berikut ${ }^{8}$ :

1. Pencurian, penyalahgunaan, atau free-riding sumber daya genetika dan/atau pengetahuan tradisional melalui sistem Paten.

2. Pengambilan, pengumpulan tanpa izin untuk tujuan komersial dari sumber daya genetika dan/atau pengetahuan tradisional.

Apabila Sumber Daya Genetika Laut dipergunakan dengan baik dan sewajarnya beriringan dengan sistem Hak Kekayaan Intelektual dan dimanfaatkan untuk kepentingan bangsa sendiri hal ini merupakan sinergi yang saling mendukung dalam memperoleh

\footnotetext{
${ }_{5}^{4}$ Sebagaimana dikutip dari paper di laman repository.usu.ac.id

${ }^{5}$ Ibid.

${ }^{6}$ Ibid.

${ }^{7}$ Ibid.

${ }^{8}$ Ibid.
} 
manfaat dari potensi Sumber Daya Genetika Laut. ${ }^{9}$ Dengan melihat kondisi yang ada saat ini, yang umumnya terjadi di negara-negara berkembang termasuk Indonesia, ternyata sistem Hak Kekayaan Intelektual belum mampu mendorong potensi ekonomi nasional dari pemanfaatan Sumber Daya Genetika Laut dan justru semakin meningkatkan terjadinya suatu misappropriation atau biopioracy.

Berdasarkan latar belakang masalah di atas maka peneliti dapat merumuskan permasalah: Bagaimana Kebijakan Pemerintah Pada Bidang Perlindungan Sumber Daya Genetika Laut di Indonesia dalam Rangka Menjaga dan Mengelola Sumber Daya Alam Laut?

\section{B. PEMBAHASAN}

Perdagangan bebas dengan beragam jenisnya telah memaksa banyaknya peran teknologi dalam mengisi slot yang kosong terkait berbagai macam bentuk permasalahan bangsa dan standar tinggi untuk meningkatkan pertumbuhan sektor ekonomi. Keadaan ini semakin menjadi sebuah simbiosis mutualisme di berbagai negara, terutama di negara-negara maju. Di berbagai negara maju, kebijakan ekonomi dan kebijakan teknologi dijadikan terkoneksi, terintegrasi dan diselaraskan untuk meningkatkan daya saing nasional di kancah global. ${ }^{10}$ Maka, salah satu kebijakan yang harus segra direalisasikan oleh pemerintah, mau tidak mau, diarahkan kepada peningkatan pemanfaatan teknologi dalam sektor produksi untuk meningkatkan pertumbuhan perekonomian nasional dan penghargaan terhadap teknologi dalam negeri. ${ }^{11}$

Indonesia merupakan negara yang memiliki kekayaan sumber daya genetika laut yang sering dimanfaatkan oleh Inventor dalam maupun luar negeri untuk menghasilkan penemuan yang baru. ${ }^{12}$ Sehingga diperlukan pengaturan secara jelas dan tegas. Pelaksanaan sistem hak kekayaan intelektual yang baik bukan saja memerlukan peraturan perundangundangan di bidang HKI yang tepat, tetapi perlu pula didukung oleh administrasi, penegakan hukum serta program sosialisasi yang optimal tentang hak kekayaan intelektual. ${ }^{13}$

Pada saat ini Indonesia telah memiliki perangkat peraturan perundang-undangan di bidang kekayaan intelektual yang melindungi sumber daya genetika laut yang cukup memadai dan tidak bertentangan dengan ketentuan sebagaimana yang dipersyaratkan dalam Persetujuan TRIPs, peraturan perundang-undangan dimaksud yaitu Undang-Undang No. 13 Tahun 2016 tentang Paten.

Secara institusional, pada saat ini telah ada Direktorat Jenderal Kekayaan Intelektual yang tugas dan fungsi utamanya salah satunya adalah menyelenggarakan administrasi hak

\footnotetext{
${ }^{9}$ Ibid.

${ }^{10}$ Seperti dikutip dari artikel di laman www.wipo.int

${ }^{11}$ Ibid.

${ }^{12}$ Ibid.

${ }^{13}$ Dikutip dari artikel di laman www.slideshare.net
} 
Paten. ${ }^{14}$ Sejak tahun 2000, pengajuan permohonan HKI dapat dilakukan di kantor-kantor wilayah Kementerian Hukum dan HAM. Selanjutnya, kantor-kantor Wilayah akan menyampaikan permohonan tersebut kepada DJKI untuk diproses lebih lanjut.

Di samping itu, pada saat ini terus mengupayakan agar tegaknya hukum Hak Kekayaan Intelektual terutama mengenai Hak Paten di bidang Sumber Daya Genetika Laut. Pemerintah secara bertahap dan berkesinambungan terus melakukan sosialisasi mengenai peran HKI terutama Paten di bidang Sumber Daya Genetika Laut di berbagai aspek kehidupan sehari-hari seperti kegiatan penelitian dan pengembangan. Tumbuhnya berbagai sentra hak kekayaan intelektual, klinik HKI, baik yang dimotori oleh Kementrian Perindustrian, Kementerian Perdagangan, Kementrian Riset, Teknologi dan Perguruan Tinggi dan Perguruan Tinggi.

Perlindungan Hak Kekayaan Intelektual di bidang sumber daya genetika laut (bioteknologi) saat ini sangat diperlukan mengingat dalam beberapa dasawarsa terakhir peranan bidang ilmu yang baru ini (bioteknologi) dalam kehidupan sehari-hari sangatlah besar. $^{15}$ Sebagai penerapan proses biologi untuk membuat produk yang berguna bagi masyarakat seperti makanan dan minuman, obat-obatan dan kompisi bahan kimia. Pemanfaatan sumber daya genetika laut melalui bioteknologi secara tepat terbukti dapat meningkatkan masyarakat, mencegah penyebarluasan penyakit dan hama, efesiensi dan kualitas produk pertanian, mutu hasil industri, dan kualitas lingkungan hidup. ${ }^{16}$

Undang-Undang No. 13 Tahun 2016 tentang Paten, Pasal 9 menyebutkan bahwa Invensi yang tidak dapat diberi Paten meliputi: proses atau produk yang pengumuman, penggunaan, atau pelaksanaannya bertentangan dengan peraturan perundang-undangan, agama, ketertiban umum, atau kesusilaan; metode pemeriksaan, perawatan, pengobatan dan/atau pembedahan yang diterapkan terhadap manusia dan/atau hewan; teori dan metode di bidang ilmu pengetahuan dan matematika; makhluk hidup, kecuali jasad renik; atau bproses biologis yang esensial untuk memproduksi tanaman atau hewan, kecuali proses nonbiologis atau proses mikrobiologis. Di samping itu, sebagaimana yang telah diuraikan di atas, berdasarkan Undang-Undang No. 29 Tahun 2000 Indonesia juga melindungi invensi mengenai varietas (baru) tanaman.

Peraturan perundang-undangan tersebut di atas diharapkan dapat mendukung ketentuan yang ditetapkan Convention on Biological Diversity $(C B D)$, yang telah diratifikasi Indonesia melalui Undang-Undang No. 5 Tahun 1994 tentang Ratifikasi Konvensi Keanekaragaman Hayati yang mencakup beberapa aspek penting sehubungan dengan akses

\footnotetext{
${ }^{14}$ Ibid.

${ }^{15}$ Ibid.

${ }^{16}$ Ibid.
} 
sumber daya genetika laut dalam ketentuan pemberian Paten, misalnya dengan menyebutkan asal usul bahan/materi yang digunakan tersebut dalam deskripsi. ${ }^{17}$

Mengingat bidang ilmu bioteknologi yang relatif baru ini erat kaitannya dengan kemungkinannya dihasilkan jasad renik (microorganisme) yang baru. Mahluk hidup pada dasarnya memang merupakan ciptaan Tuhan. Walupun demikian, atas kreativitas seseorang, maka khusus bagi jasad renik yang memenuhi kriteria Paten (terutama persyaratan mengenai kebaruan, langkah inventif, dan dapat diterapkan dalam industri) sudah selayaknya dapat diberikan Paten. Pemberian Paten tersebut merupakan penghargaan yang diberikan oleh negara atas kreativitas inventor. Kreativitas tersebut tidak hanya sekedar memilah (screen) jasad renik tertentu dari sekumpulan jasad renik, melainkan memanipulasi dan menintervensi karakteristik tertentu yang diperoleh melalui proses/kegiatan pemilihan dianggap merupakan suatu discovery dan karena itu bukan merupakan invensi yang dapat diberi Paten. Beberapa manfaat yang sangat dirasakan oleh masyarakat luas dengan pendayagunaan jasad renik atau dengan berhasil dibentuknya jasad renik baru diantaranya adalah jasad renik yang dapat dugunakan untuk menghasilkan berbagai vaksin baru, ragi yang digunakan untuk menghasilkan tempe pada temperatur rendah , jasad renik yang dapat mengkonsumsi minyak, yang bisa digunakan untuk mengatasi masalah tumpahan minyak di laut dan sebagainya. ${ }^{18}$

Invensi adalah ide inventor yang dituangkan ke dalam suatu kegiatan pemecahan masalah yang spesifik di bidang teknologi berupa produk atau proses, atau penyempurnaan atau penyempurnaan dan pengembangan produk atau proses. Jika invensi berkaitan dengan dan/atau berasal dari sumber daya genetika dan/atau pengetahuan tradisional, harus disebutkan dengan jelas dan benar asal sumber daya genetika dan/atau pengetahuan tradisional tersebut dalam deskripsi. Informasi tentang sumber daya genetika dan/atau pengetahuan tradisional ditetapkan oleh lembaga resmi yang diakui oleh pemerintah. Pembagian hasil dan/atau akses pemanfaatan sumber daya genetika dan/atau pengetahuan tradisional dilaksanakan sesuai dengan peraturan perundang-undangan dan perjanjian internasional di bidang sumber daya genetika dan pengetahuan tradisional (Pasal26 ayat (1), (2), (3) Undang-Undang No. 13 Tahun 2016).

Di Indonesia regulasi tentang Paten pertama kali diatur berdasarkan Undang-Undang Nomor no. 6 Tahun 1989. Kemudian diubah dengan Undang-undang No. 13 Tahun 1997 diubah Undang-undang No. 14 Tahun 2001 dan selanjutnya berlaku Undang-Undang No. 13 Tahun 2016 Tentang Paten . Pemaknaan tentang Paten yang menekankan pada "the originality of invention" atau keaslian invensi sebagaimana disebutkan diatas saat ini dibatasi pada penemuan yang memiliki korelasi terhadap industri saja, diluar itu Paten tidak diperkenankan lagi.

\footnotetext{
${ }^{17}$ Ibid.

18 Depertemen Perindustrian, 2007, Kebijakan Pemerintah Dalam Perlindungan Hak Kekayaan Intelektual dan Liberalisasi Perdagangan Jasa Profesi di Bidang Hukum, Jakarta, hlm. 10-11.
} 
Subjek Paten atau orang yang berhak memiliki hak Paten adalah pihak yang berhak memperoleh Paten adalah Inventor atau Orang yang menerima lebih lanjut hak Inventor yang bersangkutan. Jika Invensi dihasilkan oleh beberapa orang secara bersama-sama, hak atas Invensi dimiliki secara bersama-sama oleh para Inventor yang bersangkutan. Kecuali terbukti lain, pihak yang dianggap sebagai Inventor adalah seorang atau beberapa orang yang untuk pertama kali dinyatakan sebagai Inventor dalam Permohonan. Pemegang Paten atas Invensi yang dihasilkan oleh Inventor dalam hubungan kerja merupakan pihak yang memberikan pekerjaan, kecuali diperjanjikan lain.

Ketentuan tersebut juga berlaku terhadap Invensi yang dihasilkan, baik oleh karyawan maupun pekerja yang menggunakan data dan/atau sarana yang tersedia dalam pekerjaannya. Inventor mempunyai hak untuk memperoleh imbalan merujuk pada perjanjian atau kesepakatan yang telah dibuat dan disepakati oleh para pihak, berdasarkan pada asas kebermanfaatan secara ekonomis dari hasil penemuan yang dihasilkan oleh inventor tersebut.

Beberapa jenis imbalan, bisa diberikan berdasarkan: jumlah tertentu maupun sekaligus, persentase; gabungan antara jumlah tertentu dan sekaligus dengan hadiah atau bonus; atau bentuk lain yang telah disepakati oleh para pihak. ${ }^{19}$ Jika tidak ada kesesuaian tentang cara perhitungan dan penetapan besarnya Imbalan, maka para pihak dapat mengajukan gugatan ke Pengadilan Niaga. ${ }^{20}$ Ketentuan tersebut secara sah dan mengikat tidak menghapuskan hak Inventor untuk tetap dicantumkan namanya dalam sertifikat Paten. ${ }^{21}$ Ketentuan lebih lanjut dan lebih detail mengenai Imbalan tersebut diatur dalam Peraturan Menteri Keuangan. ${ }^{22}$

Pemegang Paten atas Invensi atau penemuan baru yang dihasilkan oleh Inventor dalam hubungan dinas dengan instansi pemerintah adalah instansi pemerintah dimaksud dan Inventor, kecuali diperjanjikan lain atau diatur lain, baik dalam peraturan perundangundangan atau dalam perjanjian diantara para pihak. ${ }^{23}$ Setelah Paten dikomersialkan, Inventor atau penemu berhak mendapatkan Imbalan atas Paten yang dihasilkannya dari sumber penerimaan negara bukan pajak. ${ }^{24}$ Dalam hal instansi pemerintah sebagai Pemegang Paten tidak dapat melaksanakan Patennya, Inventor atas persetujuan Pemegang Paten dapat melaksanakan Paten dengan pihak ketiga. ${ }^{25}$ Atas implementasi Paten tersebut, selain Pemegang Paten, Inventor bisa mendapatkan Royalti dari pihak ketiga yang memperoleh manfaat secara

\footnotetext{
${ }^{19}$ Ibid. Seperti dikutip dari artikel di laman www.wipo.int

${ }^{20}$ Ibid.

${ }^{21} \mathrm{Ibid}$.

${ }^{22}$ Ibid.

${ }^{23}$ Ibid.

${ }^{24}$ Ibid.

${ }^{25}$ Ibid.
} 
ekonomis dari komersialisasi atas Paten tersebut. Meskipun demikian, ketentuan itu tidak menghapuskan hak Inventor untuk tetap dicantumkan namanya dalam sertifikat Paten. ${ }^{26}$

Penemuan yang dapat diberikan hak Paten hanyalah penemuan baru di bidang teknologi. Penemuan dimaksud, bisa berupa teknologi yang ada dalam produk tertentu maupun cara yang dipakai dalam proses menghasilkan produk tertentu. Sehingga hak Paten bisa diberikan pada produk maupun teknologi proses produksi. Sebuah Paten menawarkan perlindungan bagi para penemu bahwa penemuan mereka tidak dapat digunakan, didistribusikan, dijual, dihasilkan secara komersial, diimpor, dieksploitasi, dan lain-lain tanpa persetujuan dari pemilik sekarang. Ini merupakan satu bentuk monopoli yang diberikan negara kepada seorang pemohon hak dengan imbalan pengungkapan informasi teknis mereka.

Adapun hak-hak yang dimiliki Pemegang Hak Paten adalah Pemegang Paten memiliki hak eksklusif untuk melaksanakan Paten yang dimilikinya dan untuk melarang pihak lain yang tanpa persetujuannya dalam hal Paten-produk: membuat, menggunakan, menjual, mengimpor, menyewakan, menyerahkan, atau menyediakan untuk dijual atau disewakan atau diserahkan produk yang diberi Paten; dan dalam hal Paten-proses: menggunakan proses produksi yang diberi Paten untuk membuat barang atau tindakan lainnya. ${ }^{27}$ Ketentuan tersebut diberlakukan untuk menghndari upaya plagiasi dan pemanfaatan atas produk yang telah diberikan atasnya Hak Paten secara illegal, sehingga Hak Paten dan pemanfaatannya bisa memberikan hasil dan dampak secara ekonomis bagi Pemegang Hak Paten.

Larangan menggunakan proses produksi yang telah diberi Paten, hanya berlaku terhadap produk impor yang semata-mata dihasilkan dari penggunaan proses yang diberi pelindungan Paten. ${ }^{28}$ Meskipun demikian, perlu kiranya dicermai bahwa terdapat pengecualian dalam kondisi tertentu. Misalnya, dalam hal untuk kepentingan pendidikan, penelitian, percobaan, atau analisis, larangan tersebut dapat dikecualikan sepanjang tidak merugikan kepentingan yang wajar dari Pemegang Paten dan tidak bersifat komersial. Pemegang Paten berhak memberikan Lisensi kepada pihak lain berdasarkan perjanjian Lisensi baik eksclusif maupun non-eksclusif. ${ }^{29}$

Pemegang Paten wajib membuat produk atau menggunakan proses di Indonesia. Membuat produk atau menggunakan proses tersebut harus menunjang transfer teknologi, penyerapan investasi dan/atau penyediaan lapangan kerja. Setiap Pemegang Paten atau penerima Lisensi Paten wajib membayar biaya tahunan. ${ }^{30}$ Kebijakan ini diambil sebagai upaya untuk memajukan pengetahuan bangsa, serta diharapkan mampu menyerap tenaga kerja

\footnotetext{
${ }^{26}$ Ibid.

${ }^{27}$ Sebagaimana dikutip dalam artikel yang dimuat dalam laman uns.ac.id

${ }^{28}$ Ibid.

${ }^{29}$ Ibid. Seperti dikutip dari artikel di laman www.wipo.int

${ }^{30}$ Ibid. Sebagaimana dikutip dalam artikel yang dimuat dalam laman uns.ac.id
} 
yang terdidik dan terlatih. Biaya tahunan yang dibebankan juga sebagai bentuk imbal jasa kepada pemerintah atas perlindungan terhadap Hak Paten inventor.

Di Indonesia, sebagaimana diatur dalam ketentuan perundang-undangan yang ada, ditentukan mengenai durasi lama waktu pemberian Hak Paten tersebut. Paten diberikan untuk jangka waktu 20 (dua puluh) tahun terhitung sejak Tanggal Penerimaan. Jangka waktu tidak dapat diperpanjang. Tanggal mulai dan berakhirnya jangka waktu Paten dicatat dan diumumkan melalui media elektronik dan/atau media non-elektronik. ${ }^{31}$ Hal ini dirasa penting agar masyarakat secara luas bisa mengakses informasi mengenai suatu produk yang telah didaftarkan dan mendapatan perlindungan Hak Paten. Sementara itu, durasi untuk Paten Sederhana diberikan untuk jangka waktu 10 (sepuluh) tahun terhitung sejak Tanggal Penerimaan. Jangka waktu tersebut tidak dapat diperpanjang. Tanggal mulai dan berakhirnya jangka waktu Paten sederhana dicatat dan diumumkan melalui media elektronik dan/atau media non-elektronik. (Pasal 22 dan 23 Undang-undang No. 13 Tahun 2016 tentang Paten).

Penemuan baru bisa dilindung hukum Paten apabila sudah memiliki sertifikat Paten. Sertifikat Paten merupakan bukti hak atas Paten. Hak atas Paten ditentukan lingkup perlindungannya berdasarkan invensi yang diuraikan dalam klaim. Hak atas Paten merupakan benda bergerak tidak berwujud. Perlindungan Paten dengan dikeluarkannya sertifikat Paten yang berlaku surut sejak Tanggal Penerimaan. ${ }^{32}$

Mengenai ketentuan pidana terhadap pelanggaran hak Paten ini diatur dalam PasalPasal berikut:

\section{Pasal 161}

Setiap Orang yang dengan sengaja dan tanpa hak melakukan perbuatan sebagaimana dimaksud dalam Pasal 160 untuk Paten, dipidana dengan pidana penjara paling lama 4 (empat) tahun dan/atau denda paling banyak Rp 1.000.000.000,00 (satu miliar rupiah).

\section{Pasal 162}

Setiap Orang yang dengan sengaja dan tanpa hak melakukan perbuatan sebagaimana dimaksud dalam Pasal 160 untuk Paten sederhana, dipidana dengan pidana penjara paling lama 2 (dua) tahun dan/atau denda paling banyak Rp500.000.000,00 (lima ratus juta rupiah).

\section{Pasal 163}

(1) Setiap orang yang melanggar ketentuan sebagaimana dimaksud dalam Pasal 161 dan/atau Pasal 162, yang mengakibatkan gangguan kesehatan dan/atau lingkungan

\footnotetext{
${ }^{31} \mathrm{Ibid}$. Seperti dikutip dari artikel di laman www.wipo.int

${ }^{32}$ Ibid.
} 
hidup, dipidana dengan pidana penjara paling lama 7 (tujuh) tahun dan/atau denda paling banyak Rp2.000.000.000,00 (dua miliar rupiah).

(2) Setiap orang yang melanggar ketentuan sebagaimana dimaksud dalam Pasal 161 dan/atau Pasal 162, yang mengakibatkan kematian manusia, dipidana dengan pidana penjara paling lama 10 (sepuluh) tahun dan/atau denda paling banyak Rp3.500.000.000,00 (tiga miliar lima ratus juta rupiah).

\section{Pasal 164}

Setiap Orang yang dengan sengaja dan tanpa hak membocorkan dokumen Permohonan yang bersifat rahasia sebagaimana dimaksud dalam Pasal 45 ayat (1) dipidana dengan pidana penjara paling lama 2 (dua) tahun.

\section{Pasal 165}

Tindak pidana sebagaimana dimaksud dalam Pasal 161, Pasal 162, dan Pasal 164 merupakan delik aduan.

Hak Paten dapat beralih atau dialihkan baik seluruhnya maupun sebagaian karena pewarisan, hibah, wasiat, wakaf, perjanjian tertulis atau sebab lain yang dibenarkan berdasarkan ketentuan peraturan perundang-undangan. Pengalihan hak atas Paten harus disertai dokumen asli Paten berikut hal lain yang berkaitan dengan Paten. Segala bentuk pengalihan hak atas Paten harus dicatat dan diumumkan dengan dikenai biaya. Terhadap pengalihan hak atas Paten yang tidak sesuai dengan ketentuan tersebut, segala hak dan kewajiban masih melekat pada Pemegang Paten. ${ }^{33}$

Pengalihan hak tidak menghapus hak inventor untuk tetap dimuat nama dan identitasnya dalam sertifikat Paten. Jika pemegang Paten atau penerima lisensi mendapati invensi yang dimilikinya diberikan atau digunakan orang lain yang tidak berhak, dapat menggugat hal tersebut ke Pengadilan Niaga sebagaimana diatur dalam Pasal 143 sampai dengan Pasal 152 Undang-Undang Paten Nomor 13 Tahun 2016. Pihak yang berhak memperoleh Paten sebagaimana dimaksud dalam Pasal 10, Pasal 11, Pasal 12, dan Pasal 13 bisa mengajukan gugatan ke Pengadilan Niaga jika suatu Paten diberikan kepada pihak lain selain dari yang berhak memperoleh Paten tersebut. ${ }^{34}$

(1) Pemegang Paten atau penerima Lisensi berhak mengajukan gugatan ganti rugi kepada Pengadilan Niaga terhadap setiap Orang yang dengan sengaja dan tanpa hak melakukan perbuatan sebagaimana dimaksud dalam Pasal 19 ayat (1).

\footnotetext{
${ }^{33}$ Ibid.

${ }^{34}$ Ibid.
} 
(2) Gugatan ganti rugi yang diajukan terhadap perbuatan sebagaimana dimaksud pada ayat (1) hanya dapat diterima jika produk atau proses itu terbukti dibuat dengan menggunakan Invensi yang telah diberi Paten.

Selain penyelesaian sengketa sebagaimana dimaksud dalam Pasal 143, para pihak dapat menyelesaikan sengketa melalui jalur arbitrase atau alternatif penyelesaian sengketa. Penyelesaian sengketa melalui jalur arbitrase ini dilaksanakan sesuai dengan ketentuan peraturan perundang-undangan. Dalam hal terjadi tuntutan pidana terhadap pelanggaran Paten atau Paten sederhana para pihak harus terlebih dahulu menyelesaikan melalui jalur mediasi. $^{35}$

Dalam bentuk mediasi, seorang mediator dalam menyelesaikan sengketa menemui para pihak atau wakilnya dengan maksud untuk mengadakan pengaturan suatu penyelesaian sengketa yang nantinya dapat diterima oleh para pihak. Namun dalam mediasi, kewenangan dan peran mediator sangat terbatas. Fungsi mediator adalah berusaha membawa dan mengajak para pihak, yang bersengketa membicarakan bersama penyelesaian sengketa dan mempersilahkan para pihak mencari dan menemukan pemecahan masalah yang dapat diterima secara mutlak.

Penyelesaian sengketa melalui arbitrase merupakan salah satu penyelesaian sengketa yang dianggap jauh lebih baik dari pada penyelesaian melalui saluran pengadilan biasa. Hal ini karena arbitrase mempunyai keunggulan tersendiri dibandingkan dengan pengadilan biasa, yaitu karena arbitrase mempunyai sifat yang agak privat yang memberikan jaminan dihindarinya publisitas, sehingga masyarakat kurang mengetahui persengketaan Paten yang terjadi. Orang takut berperkara di pengadilan karena adanya unsur publisitas ini, penyelesaian sengketa Paten melalui arbitrase melalui arbitrase relatif murah dan lebih cepat.

Pengadilan adalah benteng terakhir untuk mendapat keadilan dalam sengketa Paten atau ultimum remedium. Sengketa Paten harus mengedepankan penyelesaian perkara di luar pengadilan atau premum remedium. Ourt court system menghasilkan win-win solution bagi para pihak, misalnya melalui mediasi.

\section{PENUTUP}

Berdasarkan pembahasan yang telah diuraikan di atas, dapat disimpulkan bahwa dalam rangka melindungi pemegang Paten, maka tindakan tegas dari pemerintah dalam mencegah terjadinya pelanggaran hak Paten itu berupa ganti kerugian bagi pemegang Paten yang telah digunakan oleh pihak lain tanpa seizin pemegang Paten, dan memerintahkan si pelanggar menghentikan kegiatannya memproduksi barang yang telah dipatenkan, dan juga pemerintah segera menerbitkan Peraturan Pemerintah sebagai peraturan pelaksanaan lisensi Paten. Sebagai bentuk perlindungan hukum terhadap Paten, Undang-Undang No. 13 Tahun 
2016 tentang Paten memberikan hak kepada inventor atau pemegang Paten untuk mengajukan pengaduan dan/atau gugatan terhadap pihak yang melakukan pelanggaran Paten baik pelanggaran pidana dan/atau perdata.

\section{DAFTAR PUSTAKA}

\section{Buku :}

Agustina Soebachman, 2014, Sejarah Nusantara Berdasarkan Urutan Tahun, Surya Media Utama, Yogyakarta

Badan Penelitian dan Pengembangan Departemen Perhubungan RI, 2005. "Studi Kebutuhan SDM Transportasi Laut", Laporan Akhir Penelitian, BPP Dephub, Jakarta

Depertemen Perindustrian, 2007, Kebijakan Pemerintah Dalam Perlindungan Hak Kekayaan Intelektual dan Liberalisasi Perdagangan Jasa Profesi di Bidang Hukum, Jakarta

Richard Burton Simatupang, 2002, Aspek Hukum Dalam Bisnis, Rineka Cipta, Jakarta

\section{Makalah :}

Tatag Wiratno Pembangunan Wilayah Pesisir dan Laut Dalam Kerangka Pembangunan Ekonomi Daerah yang disampaikan pada Sosioalisasi Nasional Program MFCDP, 22 September 2004 di Jakarta

\section{Peraturan Perundang-undangan :}

Undang-Undang Nomor 13 Tahun 2016 Tentang Paten

Undang-Undang Nomor 14 tahun 2001 Tentang Paten

Undang-Undang Nomor 13 tahun 1997 Tentang Paten

Undang-Undang Nomor 5 Tahun 1994 Tentang Ratifikasi Konvensi Keanekaragaman Hayati Undang-Undang Nomor 6 tahun 1989.Tentang Paten 